\title{
EFFECT OF AGE AND STORAGE DURATION OF SEEDLING ON GROWTH AND YIELD OF WET SEASON RICE
}

\author{
P Saha ${ }^{1}$, MSU Bhuiya $^{2}$, B Karmakar ${ }^{*}$, M Salim ${ }^{2}$, B Ahmed ${ }^{1}$, P Shil ${ }^{3}$ and SK Roy 4 \\ ${ }^{1}$ Bangladesh Rice Research Institute, Gazipur, Bangladesh. \\ ${ }^{2}$ Bangladesh Agricultural University, Mymensingh, Bangladesh. \\ ${ }^{3}$ Agriculture Studies, Model Shool and College, Boyra, Khulna. \\ ${ }^{4}$ Agriculture Studies, Khulna Public College, Boyra, Khulna. \\ *Corresponding author's email: biswajitbrri@gmail.com
}

Key words: Shoot, root, biomass, leaf area index, crop growth rate.

\begin{abstract}
The experiment was conducted at the Agronomy research field of Bangladesh Agricultural University, Mymensingh from July to December 2013 to find out the effect of seedling age and storage duration on growth and yield of wet season rice. The experiment comprised of four ages of seedling (25, 30, 35 and 40-d-old) and four storage durations (0, 1, 2 and 3-days) of uprooted seedlings. Rice var. BRRI dhan52 was used as a test variety. The experiment was laid out in a split-plot design with 3 replications placing seedling age in the main plot and storage duration in the sub- plot. The effect of age and storage -duration of seedling, and their interaction were significant on growth parameters (shoot height, root length, number of tillers hill-1, leaf area index and crop growth rate), grain yield and straw yield. The growth parameters and yield exhibited a trend of decrease with the increase in seedling age and storage duration. All the growth parameters and yield showed highest value in the younger seedlings of 25-d-old with 0-day storage duration of uprooted seedlings while the lowest in the older seedlings of 40-d-old with 3-days of storage duration. The var.BRRI dhan52 produced the highest LAI (8.23), CGR (7.33 mg day ${ }^{-1}$ hill $\left.{ }^{-1}\right)$ and biomass $(26.87 \mathrm{~g})$ at 60,45 and 60 days after transplanting. Grain yield reduced by 13, 19 and $37 \%$ of 30,35 and 40 -d-old seedlings, respectively compared to 25 -d-old seedlings. In case of seedling storage, grain yield reduced by 5,14 and $31 \%$ of 1,2 and 3 -d storage, respectively compared to 0 -d storage. For optimum growth and yield of wet season rice, 25-d-old seedlings may be stored up to 1-day after uprooting taking into account the possible delay in transporting seedlings to the flood affected area from the nearby districts.
\end{abstract}

\section{Introduction}

Rice is the most important and extensively cultivated grain crop of Bangladesh. Among the groups of rice, transplanted aman rice covers the largest area of 5.60 million hectares (49.08 $\%$ of the total rice area) and contributes to $38.10 \%$ (12.89 million tons) of the total rice production in the country (BBS, 2013). The Bangladesh agriculture is prone to numerous risks and hazards like drought, salinity, excessive rainfall, flood, storm, flash flood and so on. The magnitude and frequency of flood and flash flood throughout the country are still alarming. Crop damage due to early or flash flood is very common feature in Bangladesh. Due to unexpected incessant rainfall or flash flood during wet season (aman), most of the cultivated lands of low lying area go under water causing severe damage to the rice seedlings in the freshly transplanted fields. As a result, an acute shortage of rice seedlings occurs frequently when the floodwater recedes. Farmers in flood prone areas face difficulty in double transplanting due to unavailability of seedlings. Sometimes, seedlings age is so young or too old 
Saha et al.

which would not be suitable for good harvest. At that time, rice seedlings of optimum age may be required to transport to the flood affected area from the nearby districts which may take 2 to 3 days. So, the optimum age and storage duration of uprooted seedling may contribute significantly to the growth and yield of wet season rice. Therefore, the optimum age and storage duration of uprooted seedling in the flood prone areas can play a significant role on the growth and yield of transplant aman rice. Therefore, the present study was undertaken to determine the optimum age of seedlings on storage effect exerted in wet season rice and investigate the effect of age and storage of seedlings on growth and development of wet season rice.

\section{Materials and Methods}

The experiment was conducted during the period from July to December 2013 at the Agronomy field laboratory of Bangladesh Agricultural University (BAU), Mymensingh (24 75' N latitude and 9050 ' E longitude at an elevation of $18 \mathrm{~m}$ above the sea level). The soil of the experimental land belong non-calcareous dark grey flood plain type under the old Brahmaputra Alluvial Floodplain of AEZ-9. The land was medium high with sandy loam texture having a soil $\mathrm{pH}$ of 6.40 , moderate in organic matter content. The experimental field is situated under subtropical climate. Usually the rainfall is heavy during kharif season (April to September). Rice var. BRRI dhan52, a high yielding submergence tolerant variety, was used in the experiment. The experiment consisted of two factors viz., seedling age (25, 30, 35 and 40-d-old seedlings) and storage duration of seedling after uprooting $(0,1,2$, and 3 days). The experiment was laid out in a split-plot design with 3 replications assigning seedling age in the main plots and storage duration in the sub-plots. The sprouted seeds were sown in the wet nursery bed on four dates viz., 26 June, 1 July, 6 July and 11 July in 2013 to obtained 40, 35, 30 and 25 day old seedlings for transplanting. Proper care was taken to raise the seedlings in the seedbed. Weeds were removed and irrigation was given in the nursery bed as and when necessary. The experimental land was prepared in puddle condition through ploughing and cross ploughing four times with a country plough followed by laddering to level the soil. The fertilizers urea, triple super phosphate (TSP), muriate of potash (MOP) and gypsum were applied experimental plots @ 195, 52, 82 and $60 \mathrm{~kg} \mathrm{ha}^{-1}$, respectively (BRRI, 2011). The entire amounts of TSP, MOP and gypsum were applied as basal dose at the time of final land preparation. Urea was top dressed in three equal splits at 15, 35 and 50 days after transplanting (DAT). The nursery bed was made wet by applying water on the previous days before uprooting the seedlings. The seedlings were uprooted carefully from nursery bed on 2, 3, 4 and 5 August 2013 without causing much mechanical injury to the roots and stored separately on the shade before transplanting for 3, 2, 1 and 0 day, respectively, as per treatments. Seedlings of 40, 35, 30 and 25 days with the combination of storage duration of 3,2,1 and 0 days were transplanted in the main field on 5 August, 2013 with 3 seedlings hill-1 at $25 \times 15 \mathrm{~cm}^{-1}$ spacing. Uniform management practices were followed for all the treatments. Sampling was started from 15 DAT and continued up to 60 DAT at 15 day intervals. Five hills were randomly selected and marked with the bamboo sticks in each unit plot excluding border rows. Data on Plant height, Shoot height, Root length, Number of tillers hill ${ }^{-1}$, Leaf area index (LAI), Total dry matter ( $\mathrm{g} \mathrm{hill}{ }^{-1}$ ), Crop growth rate (CGR), yield and yield components were collected . Leaf Area Index (LAI) and Crop growth rate (CGR) were calculated from the following formula expressed by Yoshida (1981) and Hunt (1978). 
Effect of Age and Storage Duration of Seedling on Growth and Yield of Wet Season Rice

Leaf Area Index (LAI): The leaf area was measured by an automatic leaf area meter (Type AAN-7, Hayashi Dam Ko Co., Japan). Leaf area index was calculated as the ratio of total leaf area and total ground area of the sample following formula expressed by Yoshida (1981) and Hunt (1978).

$$
\mathrm{LAI}=\frac{\mathrm{LA}}{\mathrm{P}}
$$

Where, $\mathrm{LA}=$ Total leaf area of the leaves of the sampled plant $\left(\mathrm{m}^{2}\right)$ and $\mathrm{P}=$ Area of the ground surface covered by the plant $\left(\mathrm{m}^{2}\right)$

Crop growth rate (CGR): Crop growth rate refers to the increase of plant dry matter per unit of time following the formula of Yoshida (1981) and Hunt (1978).

$$
C G R=\frac{W_{2}-W_{1}}{T_{2}-T_{1}}
$$

Where, $\mathrm{W}_{1}=$ Total dry matter hill ${ }^{-1}$ at time $\mathrm{T}_{1}$ and $\mathrm{W}_{2}=$ Total dry matter hill ${ }^{-1}$ at time $\mathrm{T}_{2}$ and $\left(\mathrm{T}_{2}-\mathrm{T}_{1}\right)=$ Time difference of two consecutive harvests.

The collected data were statistically analyzed using MSTAT and mean differences among the treatments was adjudged by DMRT (Gomez and Gomez, 1984).

\section{Results and Discussion}

\section{Shoot height}

Shoot height was significantly influenced by seedling age, storage duration of uprooted seedlings and their interaction at 45 and 60 DAT (Table 1). The highest shoot height was obtained at all sampling dates when 25 -d old seedlings were transplanted without storage. The shoot height exhibited a trend of decrease with the increase of age and storage durations of uprooted seedlings at all sampling dates. Similar results were found by Paul et al. (2003) and Kaykobad (2001). This reduction in shoot height might be due to better growth and vigor of the 25-d-old seedlings after transplanting. The recovery of transplanting shock is much better in younger seedlings compared to the older ones. Shoot height gradually decreased in older seedlings at all sampling dates. In general, interaction of seedling age and storage duration followed the similar trend of higher shoot height in younger seedlings without storage in all the sampling dates. Huridal et al. (1999) also obtained the similar results.

\section{Root length}

Seedling age, storage duration and their interaction had significant effect on root length at 45 and 60 DAT but it remained insignificant at 15 and 30 DAT (Table 1). The longest root length was obtained at all sampling dates when 25-d-old seedlings were transplanted and the shortest root length was recorded at all sampling dates when 40 day old seedlings were transplanted (Table 1). These findings are in conformity with Bali and Uppal (1999). The longest root length was obtained at all sampling dates with 0 -d of storage duration and the shortest root length was obtained at all sampling dates with 3-days of storage duration. These findings agree to those of Islam (1995). The recovery of transplanting shock and root formation is much better in younger seedlings compared to the older ones. Root length was gradually increased up to 45 DAT and decreased at 60 DAT in all seedling ages irrespective of younger or older ones. This 
Saha et al.

might be due to the tendency of the plant to restrict its root system within the nutrient rich top soil after the completion of establishment of the plant. Root length was gradually decreased as the age of seedlings increased at all sampling dates. Furthermore, it was gradually increased up to 45 DAT but decreased at 60 DAT in all cases of storage durations. The root length exhibited a trend of decrease with the increase in storage durations of uprooted seedlings from 0 to 3 days at all sampling dates. Interaction of age and storage of seedlings showed that 25-d-old seedlings with 0-d storage had higher root length compared to the older and stored seedlings. This indicates that both the age of seedlings and storage duration influenced root length negatively.

\section{Tillers production hill-1}

Number of tillers hill ${ }^{-1}$ was significantly influenced by seedling age, storage duration and their interaction at 30, 45 and 60 DAT (Table 2). The mean highest number (12.3) of tillers hill ${ }^{-1}$ was obtained at all sampling dates when 25-d-old seedlings were transplanted and the lowest number (9.6) of tillers hill ${ }^{-1}$ was obtained at all sampling dates when 40 -d-old seedlings were transplanted. Tillers hill ${ }^{-1}$ was gradually increased up to 45 DAT but decreased at 60 DAT in all seedling ages irrespective of younger or older ones. This might be due to the internal mechanism of the plant to produce the maximum number effective tillers hill ${ }^{-1}$ by eliminating the non-vigorous tillers. Number of tillers hill ${ }^{-1}$ was gradually decreased as the age of seedlings increased at all sampling dates (Table 2). Similar result was also observed by Haque (2002). The maximum number of tillers hill ${ }^{-1}$ was obtained at all sampling dates with 0 day of storage duration and the minimum number of tillers was obtained at all sampling dates with 3 days of storage duration. This finding was justified by Islam (1995). Number of tillers hill ${ }^{-1}$ was gradually increased up to 45 DAT but decreased at 60 DAT in all cases of storage durations. Number of tillers hill ${ }^{-1}$ exhibited a trend of decrease with the increase in storage durations of uprooted seedlings from 0 to 3 days at all sampling dates (Table 2). At all sampling dates, the maximum tillers hill ${ }^{-1}$ was obtained in 25 -d-old seedlings with 0 day storage duration while the lowest tillers hill ${ }^{-1}$ was found in 35 -d-old seedlings with 3 days storage duration at 30 DAT. Forty-d-old seedlings gave the lowest tillers hill- 1 at 45 and 60 DAT with 1 and 3 day storage duration, respectively (Table 2). This might be the cumulative effect of old age of seedlings with longer duration of storage. Both the factors discouraged early growth of tillers due to recovery shocking of the seedlings.

\section{Leaf area index (LAl)}

Leaf area index (LAI) was significantly influenced by seedling age at 30, 45 and 60 days after transplanting (DAT) (Table 2). The highest LAI was obtained at all sampling dates when 25-dold seedlings were transplanted and the lowest Leaf area index was obtained at all sampling dates when 40-d-old seedlings were transplanted. LAI gradually increased with the increase of time in all cases irrespective of the age of seedling whether it is young or old. This might be due to the internal mechanism of the plant to produce the maximum amount of food material to be accumulated in the grain by the utilization of solar radiation with the help of chlorophyll (Hunt, 1978). LAI was gradually decreased as the age of seedling increased at all sampling dates (Table 2). But it was contradictory with the result found by Hossain et al. (2011). Storage duration had significant effect on LAI at 1\% level of probability at 15, 30, 45 and 60 DAT (Table 2). The highest LAI (6.65) was obtained with 0-day of storage duration and the lowest (3.99) was obtained at all sampling dates with 3-days of storage duration at all sampling dates. LAI was gradually increased up to 60 DAT in all cases of storage durations. These findings are in line 
Effect of Age and Storage Duration of Seedling on Growth and Yield of Wet Season Rice

with Hunt (1978). LAI exhibited a trend of decrease with the increase in LAI area index was significantly influenced by the interaction between the age and storage duration of uprooted seedlings at 15, 45 and 60 DAT (Table 2). At all sampling dates, the highest LAI was obtained in 25-d-old seedlings with 0-day storage duration. LAI was the lowest at 40-d-old seedlings with 3-day storage and the values were $0.51,2.21$ and 3.01 at 15, 45 and 60 DAT, respectively (Table 2).

\section{Crop growth rate (CGR)}

Crop growth rate (CGR) was significantly affected by age and storage duration of seedlings during the period of 15-30, 30-45 and 45-60 DAT (Figure 1 and 2). The highest crop growth rate was observed during all sampling periods when 25-d-old seedlings were transplanted and the lowest crop growth rate was obtained at all sampling dates when 40-d-old seedlings were transplanted. Crop growth rate of all ages of seedlings attained peak within the period of 30-45 DAT (Figure 1). CGR changed with growth reached maximum at panicle emergence and decreased soon after (Wilson and Ellis, 1981; Tanaka, 1983). Similar results were also observed by Hossain et al. (2011). The highest CGR was obtained during all sampling periods with 0 day storage duration and the lowest crop growth rate was obtained at all sampling dates with 3 days of storage duration. Crop growth rate of all storage durations of uprooted seedlings attained peak within the period of 30-45 DAT (Figure 2). After attaining the peak, CGR gradually decreased soon after in all cases of storage durations (Tanaka, 1983). Interaction of age and storage duration of seedlings had no significant effect on CGR at 15-30 and 30-45 DAT. However, it had significant effect on CGR at 45-60 DAT.

\section{Grain yield}

Seedling age and storage duration of uprooted seedlings had significant effect on grain yield (Figure 3 and 4). These findings are in conformity with Karmakar and Sarkar (2015) and Hussain et al. (2012). Grain yield in general declined along with increased seedling age and also storage duration (Sarkar et al., 2011 and Upadhyay et al., 2003). Grain yield reduced by 13, 19 and $37 \%$ of 30,35 and 40 -d-old seedlings, respectively compared to 25 -d-old seedlings. These findings are supported by Karmakar and Sarkar (2015) who reported that yield reduced by $22 \%$ in $35-\mathrm{d}$ old seedlings compared to 14 -d old seedlings. It might be due to transplanting of younger seedlings produced higher number of panicles per unit area and more grains per panicle while older seedlings could not compete with younger seedlings in this regards. Moreover, higher sterility observed in older seedling than younger seedlings. These all together contributed to get higher yield in younger seedlings. Similar yield reduction trend also found in case of seedling storage duration. Grain yield reduced by 5, 14 and 31\% of 1, 2 and 3-d storage of seedlings, respectively compared to 0-d storage. Higher yield observed in 0-day storage duration compared 1, 2 and 3-day storage duration of seedlings. Interaction of seedling age and storage duration of uprooted seedlings had no significant effect on grain yield except 35-d old seedlings with 2-d storage (Figure 5).

\section{Conclusion}

All the growth parameters of wet season rice exhibited a trend of increase with younger seedlings and without storage of seedlings. Growth and development were gradually decreased with increased seedlings age from 25 to 40 days with storage durations ranging from 0 to 3 days. Considering the possible delay in transporting seedlings to the flood affected area from 
Saha et al.

the nearby districts, it may be concluded that 25-d-old seedlings may be kept stored up to 1 day after uprooting to get optimum growth and development that would be contributed for higher yield.

Table 1. Effect of seedling age, storage and their interaction on shoot height and root length of wet season rice

\begin{tabular}{|c|c|c|c|c|c|c|c|c|}
\hline \multirow[t]{3}{*}{ Treat. } & \multicolumn{5}{|c|}{ Shoot height $(\mathrm{cm})$} & \multicolumn{3}{|c|}{ Root length (cm) } \\
\hline & \multicolumn{4}{|c|}{ Days after transplanting } & \multicolumn{4}{|c|}{ Days after transplanting } \\
\hline & 15 & 30 & 45 & 60 & 15 & 30 & 45 & 60 \\
\hline \multicolumn{9}{|c|}{ Effect of seedling age } \\
\hline $\mathrm{A}_{1}$ & 37.3 & 56.3 & 75.9 & 89.6 & 16.33 & 19.67 & 20.92 & 16.58 \\
\hline $\mathrm{A}_{2}$ & 37.2 & 54.8 & 73.8 & 88.3 & 16.17 & 19.08 & 20.50 & 14.67 \\
\hline $\mathrm{A}_{3}$ & 35.6 & 54.3 & 71.7 & 86.9 & 15.67 & 18.33 & 19.58 & 14.83 \\
\hline $\mathrm{A}_{4}$ & 35.1 & 50.4 & 67.7 & 86.7 & 14.25 & 17.50 & 17.75 & 14.50 \\
\hline $\operatorname{LSD}(0.05)$ & 2.0 & 4.1 & 2.5 & 4.6 & - & - & 3.83 & 2.4 \\
\hline \multicolumn{9}{|c|}{ Effect of storage duration of seedling } \\
\hline $\mathrm{D}_{1}$ & 38.7 & 55.1 & 74.3 & 89.8 & 15.92 & 19.42 & 20.58 & 16.25 \\
\hline $\mathrm{D}_{2}$ & 36.8 & 54.7 & 72.3 & 88.1 & 15.58 & 19.00 & 20.08 & 14.92 \\
\hline $\mathrm{D}_{3}$ & 35.8 & 53.5 & 71.5 & 87.2 & 15.75 & 18.33 & 19.42 & 14.25 \\
\hline $\mathrm{D}_{4}$ & 34.3 & 52.7 & 71.1 & 86.4 & 15.17 & 17.83 & 18.67 & 14.17 \\
\hline LSD (0.05) & 3.3 & 2.2 & 3.4 & 4.4 & - & - & 2.18 & 2.25 \\
\hline \multicolumn{9}{|c|}{ Interaction effect of age and storage duration of seedling } \\
\hline $\mathrm{A}_{1} \mathrm{D}_{1}$ & 40.7 & 60.7 & 78.7 & 98.0 & 18.00 & 22.67 & 22.33 & 17.00 \\
\hline$A_{1} D_{2}$ & 40.0 & 59.0 & 78.0 & 89.3 & 16.33 & 18.00 & 21.67 & 16.00 \\
\hline$A_{1} D_{3}$ & 35.3 & 55.3 & 74.7 & 85.7 & 16.00 & 19.33 & 22.30 & 15.00 \\
\hline$A_{1} D_{4}$ & 34.7 & 56.7 & 72.3 & 85.3 & 16.33 & 21.67 & 18.33 & 14.33 \\
\hline$A_{2} D_{1}$ & 40.3 & 54.3 & 73.3 & 89.0 & 16.67 & 18.33 & 21.33 & 16.67 \\
\hline$A_{2} D_{2}$ & 36.3 & 55.7 & 72.3 & 86.0 & 14.00 & 19.67 & 22.23 & 13.67 \\
\hline$A_{2} D_{3}$ & 38.3 & 52.7 & 73.7 & 89.3 & 16.67 & 19.33 & 19.00 & 13.67 \\
\hline$A_{2} D_{4}$ & 33.7 & 50.3 & 76.0 & 88.7 & 16.00 & 16.00 & 19.33 & 14.67 \\
\hline$A_{3} D_{1}$ & 34.7 & 53.7 & 69.7 & 86.7 & 15.00 & 22.00 & 21.33 & 14.33 \\
\hline$A_{3} D_{2}$ & 37.0 & 53.7 & 71.3 & 91.0 & 17.33 & 16.33 & 19.00 & 15.00 \\
\hline $\mathrm{A}_{3} \mathrm{D}_{3}$ & 36.0 & 58.7 & 73.3 & 84.7 & 16.67 & 17.33 & 18.33 & 14.67 \\
\hline $\mathrm{A}_{3} \mathrm{D}_{4}$ & 35.3 & 51.3 & 72.3 & 85.3 & 13.67 & 17.67 & 18.67 & 15.33 \\
\hline $\mathrm{A}_{4} \mathrm{D}_{1}$ & 39.0 & 51.7 & 75.3 & 85.3 & 15.33 & 17.67 & 17.33 & 17.00 \\
\hline $\mathrm{A}_{4} \mathrm{D}_{2}$ & 34.0 & 50.3 & 67.3 & 86.0 & 14.67 & 19.00 & 17.23 & 15.00 \\
\hline $\mathrm{A}_{4} \mathrm{D}_{3}$ & 33.7 & 47.3 & 64.3 & 89.0 & 12.33 & 17.33 & 18.00 & 13.67 \\
\hline $\mathrm{A}_{4} \mathrm{D}_{4}$ & 33.3 & 52.3 & 63.7 & 86.3 & 14.67 & 16.00 & 18.33 & 12.33 \\
\hline $\mathrm{LSD}_{0.05}$ & 6.6 & 7.3 & 6.8 & 8.9 & ns & ns & 4.36 & 4.51 \\
\hline
\end{tabular}

In a column, figures having common letter(s) do not differ significantly whereas the figures with dissimilar letters differ significantly as adjusted by DMRT

$A_{1}=25, A_{2}=30, A_{3}=35$ and $A_{4}=40$-d old seedling. $D_{1}=0, D_{2}=1, D_{3}=2$ and $D_{4}=3$ days storage duration. 
Effect of Age and Storage Duration of Seedling on Growth and Yield of Wet Season Rice

Table 2. Effect of seedling age, storage and their interaction on tillers hill ${ }^{-1}$ and leaf area index of wet season rice

\begin{tabular}{|c|c|c|c|c|c|c|c|c|}
\hline \multirow[t]{3}{*}{ Treat. } & \multicolumn{4}{|c|}{ Tillers hill- $^{-1}$ (no.) } & \multicolumn{4}{|c|}{ Leaf area index } \\
\hline & \multicolumn{4}{|c|}{ Days after transplanting } & \multicolumn{4}{|c|}{ Days after transplanting } \\
\hline & 15 & 30 & 45 & 60 & 15 & 30 & 45 & 60 \\
\hline \multicolumn{9}{|c|}{ Effect of seedling age } \\
\hline $\mathrm{A}_{1}$ & 5.6 & 10.8 & 13.0 & 12.3 & 0.84 & 2.95 & 4.50 & 6.71 \\
\hline $\mathrm{A}_{2}$ & 5.5 & 10.5 & 11.8 & 11.2 & 0.82 & 2.51 & 4.11 & 6.10 \\
\hline $\mathrm{A}_{3}$ & 5.5 & 8.4 & 10.9 & 9.9 & 0.74 & 2.42 & 3.78 & 4.88 \\
\hline $\mathrm{A}_{4}$ & 4.7 & 9.6 & 10.2 & 9.7 & 0.73 & 1.88 & 3.57 & 4.50 \\
\hline $\operatorname{LSD}(0.05)$ & - & 3.3 & 2.2 & 0.6 & - & 0.28 & 0.65 & 0.56 \\
\hline \multicolumn{9}{|c|}{ Effect of storage duration of seedling } \\
\hline $\mathrm{D}_{1}$ & 5.6 & 10.6 & 12.7 & 11.5 & 1.04 & 2.98 & 4.90 & 6.65 \\
\hline $\mathrm{D}_{2}$ & 5.4 & 10.2 & 11.8 & 10.9 & 0.68 & 2.60 & 4.10 & 6.33 \\
\hline $\mathrm{D}_{3}$ & 5.4 & 9.3 & 11.1 & 10.7 & 0.73 & 2.32 & 4.03 & 5.22 \\
\hline $\mathrm{D}_{4}$ & 4.9 & 9.3 & 10.4 & 10.3 & 0.67 & 1.86 & 2.92 & 3.99 \\
\hline $\operatorname{LSD}(0.05)$ & 0.81 & 2.5 & 1.4 & 1.1 & 0.2 & 0.3 & 0.5 & 0.4 \\
\hline \multicolumn{9}{|c|}{ Interaction effect of age and storage duration of seedling } \\
\hline $\mathrm{A}_{1} \mathrm{D}_{1}$ & 6.3 & 13.0 & 15.0 & 14.0 & 1.26 & 3.44 & 5.47 & 8.23 \\
\hline$A_{1} D_{2}$ & 6.0 & 11.7 & 13.7 & 12.5 & 0.64 & 3.26 & 4.79 & 7.05 \\
\hline$A_{1} D_{3}$ & 5.0 & 8.3 & 13.3 & 9.3 & 0.54 & 2.58 & 4.58 & 6.21 \\
\hline $\mathrm{A}_{1} \mathrm{D}_{4}$ & 5.3 & 11.6 & 10.0 & 13.0 & 0.51 & 2.53 & 3.83 & 5.35 \\
\hline$A_{2} D_{1}$ & 6.2 & 10.7 & 12.6 & 12.3 & 1.18 & 3.12 & 4.09 & 6.82 \\
\hline$A_{2} D_{2}$ & 5.3 & 11.7 & 14.3 & 12.7 & 0.67 & 2.72 & 4.68 & 7.96 \\
\hline$A_{2} D_{3}$ & 5.7 & 9.3 & 8.3 & 10.5 & 0.75 & 2.53 & 4.54 & 5.20 \\
\hline $\mathrm{A}_{2} \mathrm{D}_{4}$ & 4.7 & 9.0 & 12.0 & 9.0 & 0.75 & 1.68 & 3.12 & 4.41 \\
\hline$A_{3} D_{1}$ & 5.0 & 12.0 & 11.0 & 9.7 & 1.00 & 2.90 & 5.26 & 6.26 \\
\hline$A_{3} D_{2}$ & 6.0 & 7.6 & 12.0 & 9.0 & 0.66 & 2.44 & 3.77 & 5.15 \\
\hline$A_{3} D_{3}$ & 5.7 & 8.0 & 11.6 & 10.6 & 0.88 & 2.43 & 3.55 & 4.95 \\
\hline $\mathrm{A}_{3} \mathrm{D}_{4}$ & 5.3 & 6.0 & 9.0 & 10.3 & 0.73 & 1.90 & 2.53 & 3.18 \\
\hline $\mathrm{A}_{4} \mathrm{D}_{1}$ & 5.0 & 6.3 & 12.0 & 8.9 & 0.71 & 2.45 & 4.79 & 5.30 \\
\hline $\mathrm{A}_{4} \mathrm{D}_{2}$ & 4.0 & 10.0 & 7.0 & 9.3 & 0.75 & 2.00 & 3.15 & 5.18 \\
\hline $\mathrm{A}_{4} \mathrm{D}_{3}$ & 5.3 & 11.6 & 11.0 & 12.0 & 0.75 & 1.73 & 3.44 & 4.51 \\
\hline $\mathrm{A}_{4} \mathrm{D}_{4}$ & 4.3 & 10.3 & 10.6 & 8.7 & 0.71 & 1.35 & 2.21 & 3.01 \\
\hline LSD (0.05) & ns & 4.93 & 2.8 & 2.2 & 0.28 & ns & 0.94 & 0.75 \\
\hline
\end{tabular}

In a column, figures having common letter(s) do not differ significantly whereas the figures with dissimilar letters differ significantly as adjusted by DMRT

$A_{1}=25, A_{2}=30, A_{3}=35$ and $A_{4}=40$-d old seedling. $D_{1}=0, D_{2}=1, D_{3}=2$ and $D_{4}=3$ days storage duration. 
Saha et al.

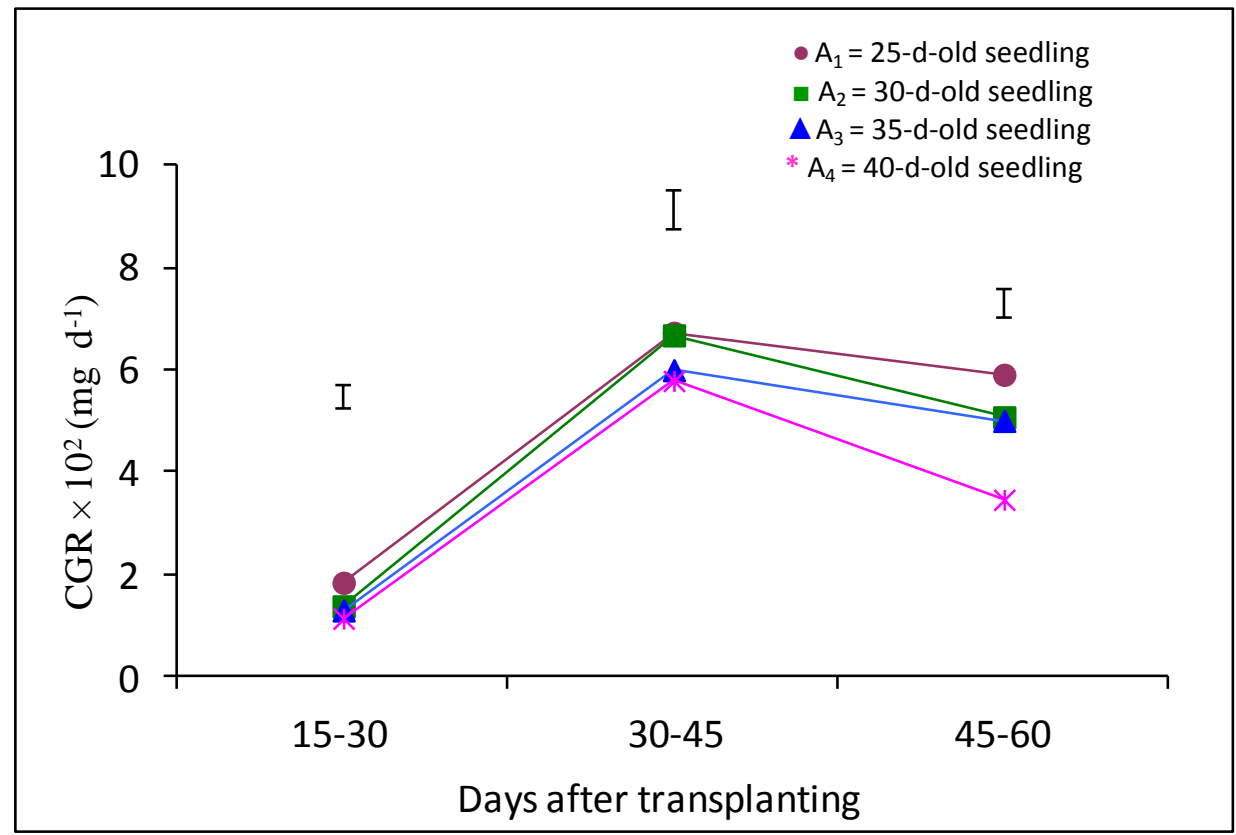

Fig. 1. Crop growth rate (CGR) of wet season rice as influenced by age of seedling at different days after transplanting.

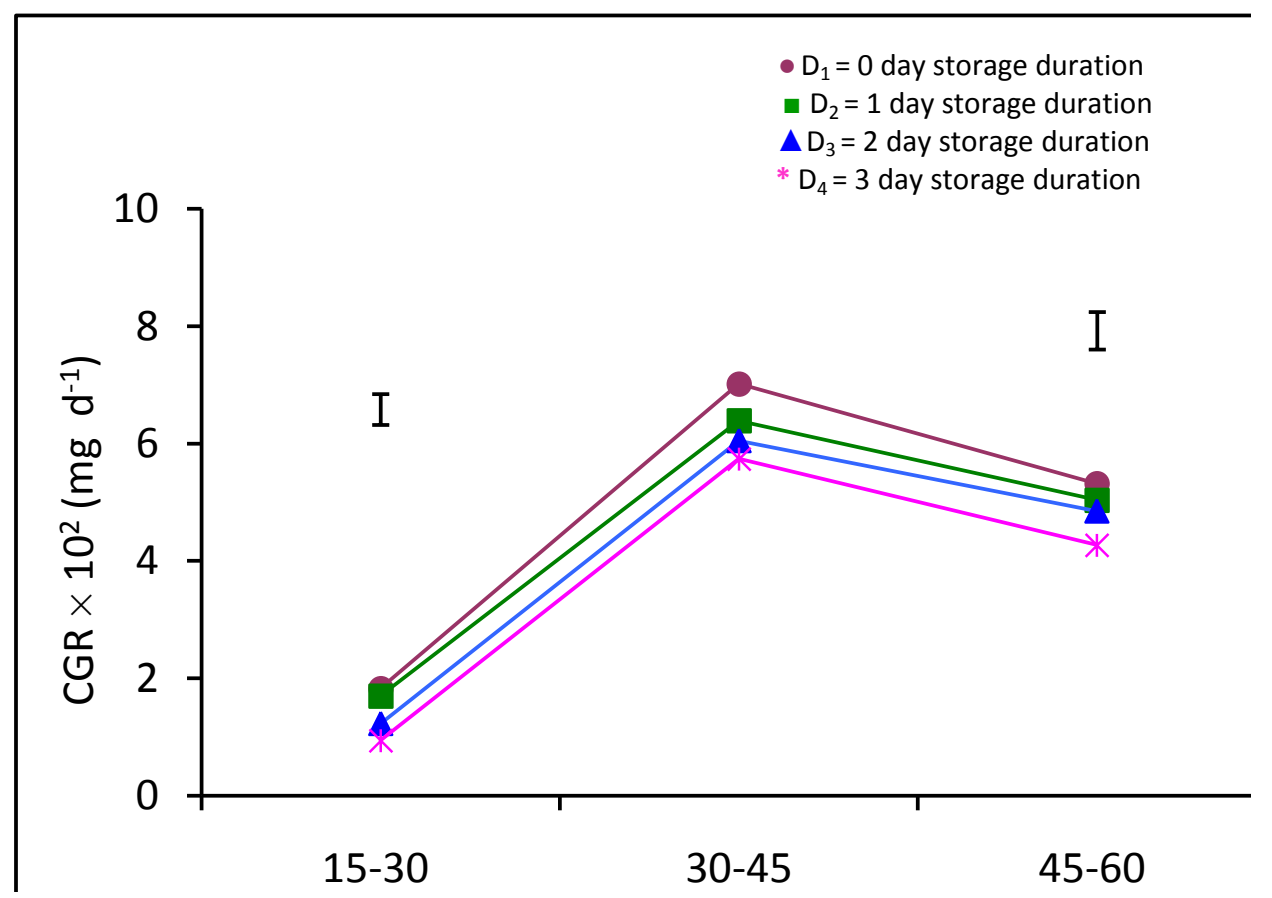

Fig. 2. Crop growth rate (CGR) of wet season man rice as influenced by storage duration of seedling at different days after transplanting 
Effect of Age and Storage Duration of Seedling on Growth and Yield of Wet Season Rice

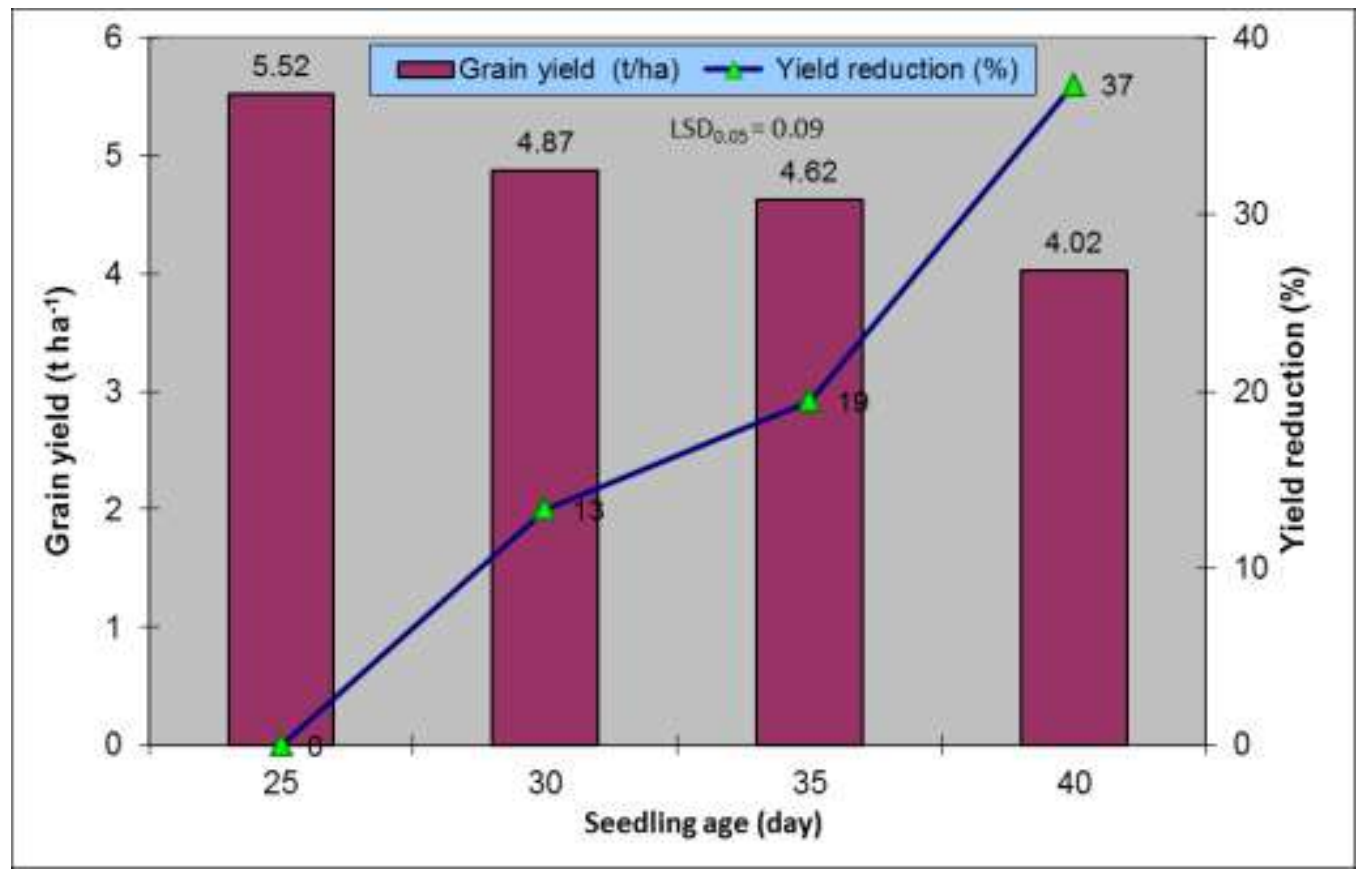

Fig. 3. Effect of seedling age on grain yield of var. BRRI dhan52 and yield reduction of 30, 35 and 40-d old seedling compared to 25-d old seedling.

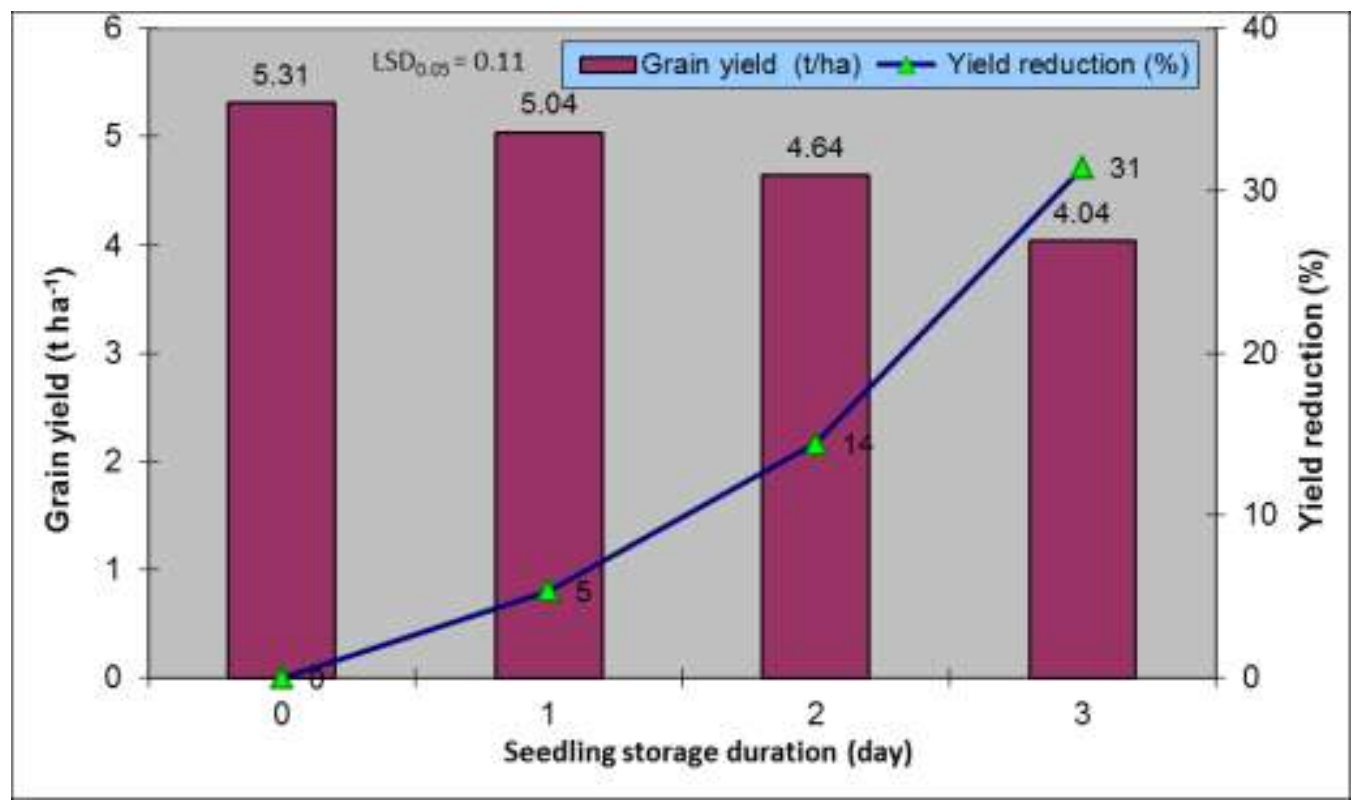

Fig. 4. Effect of storage duration of seedling on grain yield of var. BRRI dhan52 and yield reduction of 30, 35 and 40-d old seedling compared to 25 -d old seedling. 
Saha et al.

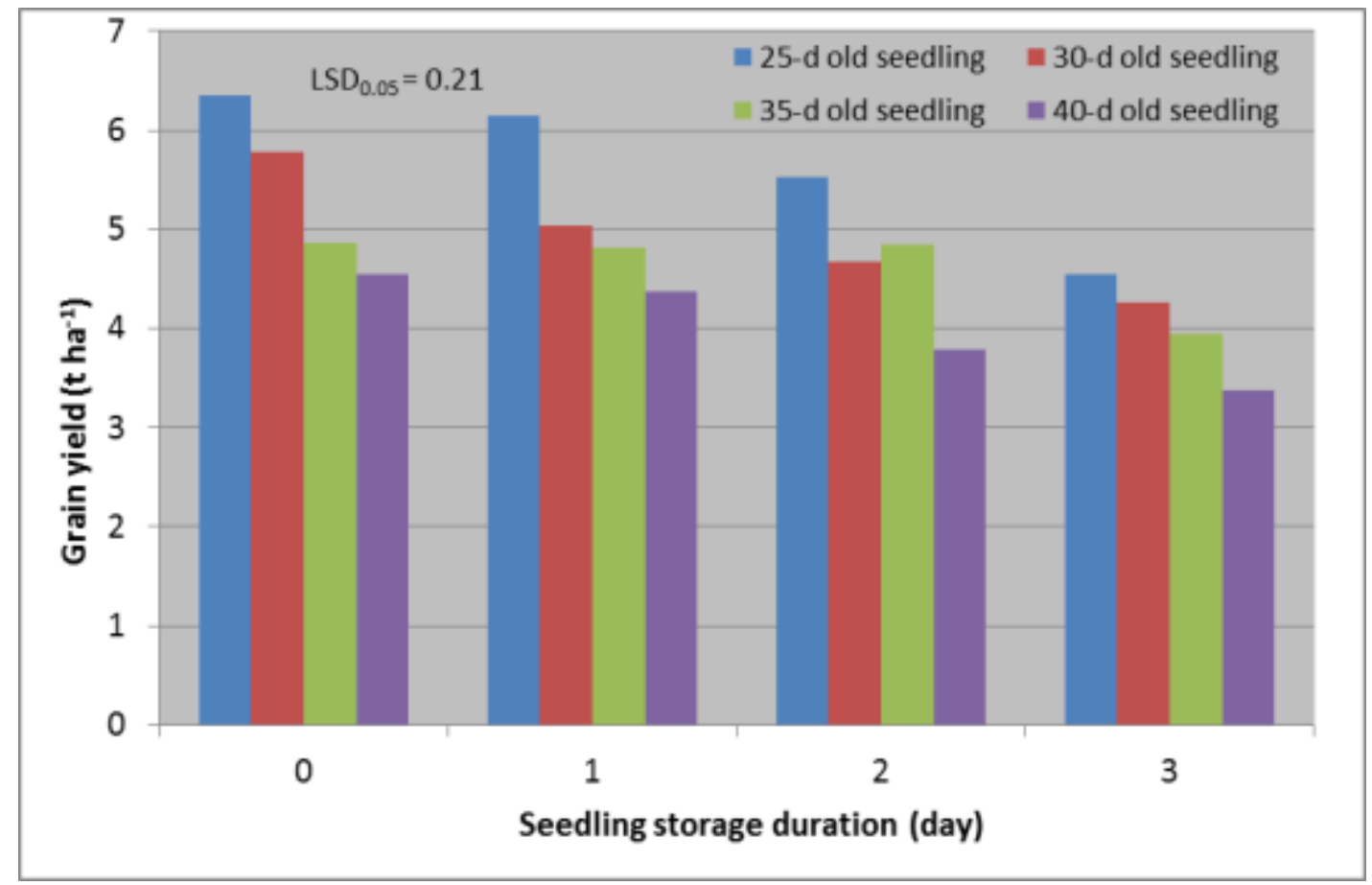

Fig. 5. Interaction effect of seedling age and storage duration on grain yield of var. BRRI dhan52 of 30, 35 and 40-d old seedling compared to 25 -d old seedling.

\section{Reference}

Bali, A. S. and H. S. Uppal. 1999. Soil nitrate profile and root growth of basmati rice under varying transplanting dates and irrigation regimes. Applied Biol. Res. 1(1): 25-28.

BBS (Bangladesh Bureau of Statistics) 2013. Monthly Statistical Bulletin of Bangladesh, Bangladesh Bureau of Statistics, Statistics Division, Min. Plan., Govt. of People's Repub. of Bangladesh, Dhaka. pp. 71.

BRRI (Bangladesh Rice Research Institute) 2011. Annual Report for 2010. Bangladesh Rice Res. Inst., Joydebpur, Gazipur. pp. 73-77.

Gomez, K. A and A. A. Gomez. 1984. Statistical procedure for Agril. Res. Intl. Rice Res. Inst., John Wiley and Sons. New York, Chichester, Brisbane, Toronto, Singapore. pp. 139-240.

Haque, D. E. 2002. Effect of Madagascar technique of younger seedling and wider spacing on growth and yield of Boro rice. MS Thesis, Dept. Agron., Bangladesh Agril. Univ., Mymensingh. pp. 28-71.

Hossain, M. A., M. A. R. Sarkar and S. K. Paul. 2011. Growth of transplant aman rice as affected by row arrangement, age of tiller seedlings and number of tiller seedlings hill ${ }^{-1}$. Tropical Agril. Res. and Extension. 14 (4) (in press).

Hunt, R. 1978. Plant Growth Analysis. Study in Biology No. 96. Edward Arnold, London. pp. 2730. 
Effect of Age and Storage Duration of Seedling on Growth and Yield of Wet Season Rice

Hunt, R. 1978. The filled curve in plant growth studies. Math and plant physiology (Eds. Rose, D.A. and Edwards, D.A.C.). Aca. Press, London. pp. 283-298.

Huridal, S. S., K. Prabhuyot and P. Kaur. 1999. Evaluation of agronomic practices for rice using computer simulation model. CERES-Rice. Oryza. 36(1): 63-65.

Islam, M. S. 1995. Effect of variety and storing time of seedlings on the yield of Boro rice. MS Thesis, Dept. Agron., Bangladesh Agril. Univ., Mymensingh. pp. 6.

Karmakar B, M. A. R. Sarkar. 2015. Optimizing seedling age of promising rice genotypes in rainfed environment. Journal of Crop and Weed, 11: 149-160.

Kaykobad, S. A. M. 2001. Effect of storage conditions and storage durations of uprooted seedlings on the yield and yield contributing characters of transplant aman rice cv. Binashail. MS Thesis, Dept. of Agron., Bangladesh Agril. Univ., Mymensingh. pp. 36.

Paul, S. K., M. A. R. Sarkar and M. Ahmed. 2003. Leaf production, leaf and culm dry matter yield of transplant aman rice as affected by row arrangement and tiller separation. Asian J. Plant Sci. 5: 161-166.

Sarkar, M. A. R, S. K. Paul, M. A. Hossain 2011. Effect of row arrangement, age of tiller seedlings and number of tiller seedlings hill-1 ${ }^{-1}$ on performance of transplant aman rice. Agril Sci. J. 6 (2): 59-68.

Singh, R. S. and S. B. Singh. 1998. Response of rice (Oryza sativa L.) to age of seedlings and level and time of application of nitrogen under irrigated condition. Ind. J. Agron. 43(4): 632635.

Tanaka, A. 1983. Physiological aspects of productivity. In: Potential productivity of yield crops under different environments. IRRI. Los Banos, Phillippines. pp. 77-78.

Upadhyay V. V., R. Mathew, S. K. Vishwakarma, V. K. Shukla. 2003. Effect of number of seedlings per hill and age of seedlings on productivity and economics of transplanted rice. JNKVV. Res. J. 37(1): 27-29.

Wilson, J. H. and Ellis, R. D. 1981. Supply of dry matter from stem and seed in rice grown under dry land conditions. Intl. Rice Res. Newsl. 6(1): 23-24.

Yoshida, S. 1981. Physiological Analysis of Rice Yield. In: "Fundamentals of Rice crop Science". Intl. Rice Res. Inst., Los Banos, Phillippines. pp. 269. 